\title{
molecules
}

ISSN 1420-3049

www.mdpi.com/journal/molecules

Article

\section{Secondary Metabolites from Two Species of Tolpis and Their Biological Activities}

\author{
Jorge Triana ${ }^{1}{ }^{1}$, Mariana López ${ }^{1}$, Francisco Javier Pérez ${ }^{1}$, Milagros Rico ${ }^{1}$, Aroa López ${ }^{1}$, \\ Francisco Estévez ${ }^{2,3}$, María Teresa Marrero ${ }^{2}$, Ignacio Brouard ${ }^{4}$ and Francisco León ${ }^{4, *}$
}

1 Departamento de Química, Unidad Asociada al CSIC, Universidad de Las Palmas de Gran Canaria, Campus de Tafira, 35017, Las Palmas de Gran Canaria, Spain; E-Mails: mlopez@dqui.ulpgc.es (M.L.); fperez@dqui.ulpgc.es (F.J.P.); mrico@dqui.ulpgc.es (M.R.); aroa2412@gmail.com (A.L.)

2 Departamento de Bioquímica, Unidad Asociada al CSIC, Universidad de Las Palmas de Gran Canaria, Plaza Dr. Pasteur s/n, 35016, Las Palmas de Gran Canaria, Spain; E-Mails: festevez@dbbf.ulpgc.es (F.E.); mariatemarrero@gmail.com (M.T.M.)

3 Fundación Canaria Instituto Canario de Investigación del Cáncer, Torre Agustín Arévalo- $7^{a}$ Planta (PCTT-ULL) Avda de la Trinidad s/n 38204 San Cristóbal de La Laguna-S/C de Tenerife, Spain

4 Instituto de Productos Naturales y Agrobiología, Consejo Superior de Investigaciones Científicas (CSIC), Avda. Astrofísico F. Sánchez, 3, 38206 La Laguna, Spain; E-Mail: ibrouard@ipna.csic.es

* Authors to whom correspondence should be addressed; E-Mails: jtriana@dqui.ulpgc.es (J.T.); jfleon.oyola@gmail.com (F.L.); Tel.: +34-922-256847 (ext. 224) (F.L.); Fax: +34-922-260135 (F.L.).

Received: 27 September 2012; in revised form: 24 October 2012 / Accepted: 26 October 2012 / Published: 1 November 2012

\begin{abstract}
Phytochemical research of two Tolpis species, T. proustii and T. lagopoda, led to the isolation of three new compounds: 30-chloro-3 $\beta$-acetoxy-22 $\alpha$-hydroxyl-20(21)-

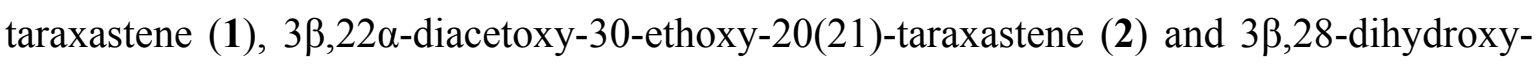
$11 \alpha$-hydroperoxy-12-ursene (3). The structures of the new compounds were elucidated by means of extensive IR, NMR, and MS data and by comparison of data reported in the literature. The in vitro antioxidant activities of the extracts were assessed by the DPPH and ABTS scavenging methods. The cytotoxicity of several known compounds and its derivatives was also assessed against human myeloid leukemia K-562 and K-562/ADR cell lines.
\end{abstract}

Keywords: Asteraceae; Tolpis proustii; Tolpis lagopoda; ursane-triterpenes; taraxastane-triterpenes 


\section{Introduction}

The Tolpis genus (Asteraceae: Cichorioideae, Cichoriinae) consists of some 20 species distributed throughout Europe, North Africa, Canary Islands, Cape Verde and Asia, this genus being represented in the Canary Islands by around ten species [1].

Although a wide-ranging study of different species of Tolpis from the Canary Islands and from other Macaronesian archipelagos has been carried out from the botanical point of view [2,3], only one phytochemical report has previously appeared on the isolation and structural elucidation of aromatic compounds, triterpenes, and sterols from T. webbi and T. spp [4].

As a part of our continuing search for novel, plant-derived biological agents and our systematic investigation of the composition of Canarian endemic plants, the present work describes the isolation and structural elucidation of the constituents of the ethanolic extracts of the aerial parts of T. proustii Pitard in Pitard and Proust and T. lagopoda C.Sm. ex Buch. The constituents of these extracts were purified by CC, MPLC and preparative TLC. The structures of the known compounds were confirmed by comparison of their spectroscopic data with those reported in the literature.

From $T$. proustii seventeen compounds were isolated including two taraxan-triterpenoid 30-chloro-

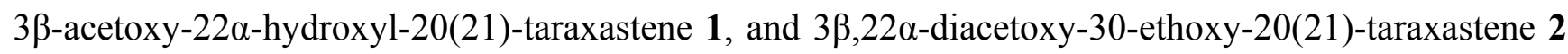

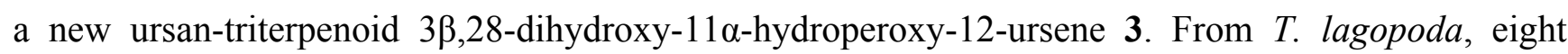

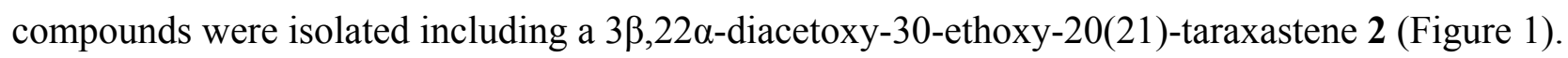

Figure 1. Compounds 1-3 isolated of the T. proustii and T. lagopoda.

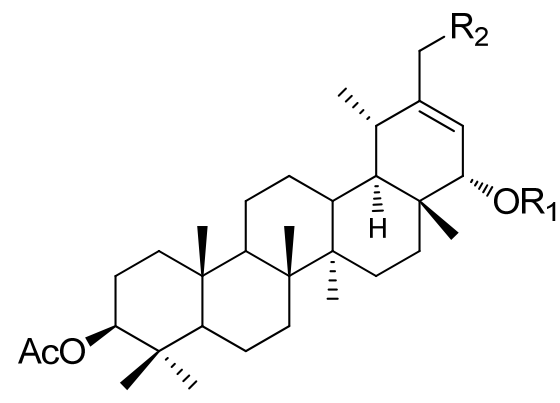

$1 \mathrm{R}_{1}=\mathrm{H} ; \mathrm{R}_{2}=\mathrm{Cl}$

1a $\mathrm{R}_{1}=\mathrm{AC} ; \mathrm{R}_{2}=\mathrm{Cl}$

$2 \mathrm{R}_{1}=\mathrm{Ac} ; \mathrm{R}_{2}=\mathrm{OEt}$

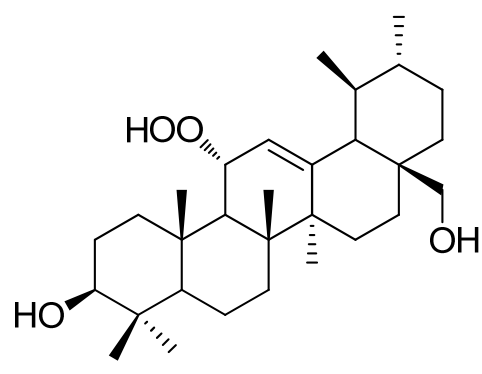

3

The high level of solar radiation and the high temperature prevailing in the region of the Canary Islands (opposite the northwest coast of Africa) force plants to develop defence mechanisms against ultraviolet radiation and excessive production of free radicals through the accumulation of antioxidant metabolites [5]. This prompted us to evaluate the antioxidant activity of the crude extract of T. proustii and T. lagopoda, and that of some of the isolated compounds. Furthermore, one of the most important mechanisms by which tumor cells resist to cytotoxic effects of a variety of chemotherapeutic drugs is overexpression of the human multidrug resistance (MDR1) gene and its product, P-glycoprotein [6]. Here we have evaluated the effects of natural compounds and derivatives on the growth of the human leukemia K-562 and the P-glycoprotein-overexpressing K-562/ADR cell lines. 


\section{Results and Discussion}

\subsection{Structure Elucidation of Compounds 1-3}

The positive EIMS spectrum of compound 1 showed a molecular ion at $m / z \quad 518 / 520$ (3:1) in agreement with the presence of a chlorine atom in the structure, and with the formula $\mathrm{C}_{32} \mathrm{H}_{51} \mathrm{O}_{3} \mathrm{Cl}$ for this compound. In the same spectrum, the ions at $m / z$ 500/502 $\left[\mathrm{M}-\mathrm{H}_{2} \mathrm{O}\right]^{+}, 458 / 460\left[\mathrm{M}-\mathrm{CH}_{3} \mathrm{COOH}\right]^{+}$ suggested that this compound contained a hydroxyl and an acetyl group, respectively. Confirmed by the IR spectrum with absorptions of a hydroxyl $3446 \mathrm{~cm}^{-1}$ and a carbonyl $1730 \mathrm{~cm}^{-1}$ group. Its HREIMS experiment indicated the molecular formula $\mathrm{C}_{32} \mathrm{H}_{51} \mathrm{O}_{3}{ }^{37} \mathrm{Cl}$ (calcd. for $[\mathrm{M}]^{+}$520.3497; found 520.3497) and $\mathrm{C}_{32} \mathrm{H}_{51} \mathrm{O}_{3}{ }^{35} \mathrm{Cl}$ (calcd. for $[\mathrm{M}]^{+}$518.3527; found 518.3517). All spectral data suggested that 1 was a pentacyclic triterpene with a trisubstituted double bond in the $\mathrm{E}$ ring [7] with a 20(21)-taraxastane structure.

The ${ }^{1} \mathrm{H}$ and ${ }^{13} \mathrm{C}-\mathrm{NMR}$ (Table 1) spectra of $\mathbf{1}$ showed the presence of the oxygenated methine proton at $\delta_{\mathrm{H}} 3.35(1 \mathrm{H}, \mathrm{d}, J=6.6 \mathrm{~Hz})$ and an unusual chloro atom at $\mathrm{C}-30$ at $\delta_{\mathrm{C}} 47.6$ (Table 1). The structure elucidation and NMR assignments were therefore based primarily on the results of COSY, HSQC, HMBC, and NOESY experiments (Figure 2).

Table 1. ${ }^{1} \mathrm{H}$ - and ${ }^{13} \mathrm{C}-\mathrm{NMR}$ data for compounds $\mathbf{1}, \mathbf{1 a}$ and $\mathbf{2}^{a}$.

\begin{tabular}{|c|c|c|c|c|c|c|}
\hline \multirow[b]{2}{*}{ Position } & \multicolumn{2}{|l|}{1} & \multicolumn{2}{|c|}{$1 \mathrm{a}$} & \multicolumn{2}{|c|}{2} \\
\hline & $\delta_{\mathrm{H}}$ & $\delta_{\mathrm{C}}$ & $\delta_{\mathrm{H}}$ & $\delta_{\mathrm{C}}$ & $\delta_{\mathrm{H}}$ & $\delta_{\mathrm{C}}$ \\
\hline 1 & $1.65 *$ & 38.5 & $1.65 *$ & 38.7 & $1.60 *$ & 38.5 \\
\hline 2 & $1.50 *$ & 23.7 & $1.54 *$ & 21.7 & $1.55 *$ & 23.7 \\
\hline 3 & $\begin{array}{c}4.41 \mathrm{dd} \\
(6.1,10.8)\end{array}$ & 81.0 & $\begin{array}{c}4.43 \mathrm{dd} \\
(6.4,10.0)\end{array}$ & 81.1 & $\begin{array}{c}4.43 \mathrm{dd} \\
(5.110 .4)\end{array}$ & 81.0 \\
\hline 4 & - & 38.3 & - & 38.0 & - & 37.8 \\
\hline 5 & $0.75 *$ & 55.4 & $0.74 *$ & 55.6 & $0.75 *$ & 55.4 \\
\hline 6 & $\begin{array}{l}1.45 * \\
1.35 *\end{array}$ & 18.2 & $\begin{array}{l}1.44 * \\
1.34 *\end{array}$ & 18.0 & $1.30 *$ & 18.2 \\
\hline 7 & $1.35 *$ & 34.2 & $1.34 *$ & 34.4 & $1.35 *$ & 34.2 \\
\hline 8 & - & 41.2 & - & 41.3 & - & 41.1 \\
\hline 9 & $1.25 *$ & 50.3 & $1.26 *$ & 50.6 & $1.25 *$ & 50.4 \\
\hline 10 & - & 37.1 & - & 37.3 & - & 37.1 \\
\hline 11 & $1.20 *$ & 21.6 & $1.21 *$ & 21.4 & $1.20 *$ & 21.6 \\
\hline 12 & $\begin{array}{l}1.60 * \\
1.20 *\end{array}$ & 27.6 & $1.60 *$ & 27.7 & $1.58 *$ & 27.5 \\
\hline 13 & $0.95 *$ & 38.6 & $0.95 *$ & & $1.66 *$ & 38.6 \\
\hline 14 & - & 42.3 & - & 42.4 & - & 42.3 \\
\hline 15 & $\begin{array}{c}1.72 * \\
1.05 \mathrm{ddd} \\
(2.5,4.0,13.05)\end{array}$ & 26.7 & $\begin{array}{l}1.71 * \\
1.02 *\end{array}$ & 29.9 & $1.50 *$ & 26.6 \\
\hline 16 & $\begin{array}{c}0.95 * \\
1.85 \mathrm{dt}(9.0,13.0)\end{array}$ & 29.7 & $0.95 *$ & 29.9 & $1.60 *$ & 29.9 \\
\hline 17 & - & 37.8 & - & 37.4 & - & 37.2 \\
\hline 18 & $1.45 *$ & 40.5 & $1.44 *$ & 41.5 & $1.45 *$ & 41.5 \\
\hline
\end{tabular}


Table 1. Cont.

\begin{tabular}{|c|c|c|c|c|c|c|}
\hline \multirow[b]{2}{*}{ Position } & \multicolumn{2}{|l|}{1} & \multicolumn{2}{|c|}{$1 \mathbf{a}$} & \multicolumn{2}{|c|}{2} \\
\hline & $\delta_{\mathrm{H}}$ & $\delta_{\mathrm{C}}$ & $\delta_{H}$ & $\delta_{\mathrm{C}}$ & $\delta_{\mathrm{H}}$ & $\delta_{\mathrm{C}}$ \\
\hline 19 & $2.00 \mathrm{t}(7.0)$ & 31.6 & $2.03 \operatorname{tbr}(7.0)$ & 31.7 & $1.79 \mathrm{q}(6.6)$ & 32.3 \\
\hline 20 & - & 144.9 & - & 146.5 & - & 147.7 \\
\hline 21 & $5.89 \mathrm{~d}(6.5)$ & 126.3 & $5.87 \mathrm{~d}(6.4)$ & 123.1 & $5.75 \mathrm{~d}(6.3)$ & 119.2 \\
\hline 22 & $3.35 \mathrm{dbr}(6.6)$ & 73.3 & $4.51 \mathrm{~d}(6.4)$ & 75.3 & $4.55 \mathrm{~d}(6.3)$ & 75.3 \\
\hline 23 & $0.78 \mathrm{~s}$ & 28.0 & $0.79 \mathrm{~s}$ & 28.1 & $0.81 \mathrm{~s}$ & 28.0 \\
\hline 24 & $0.77 \mathrm{~s}$ & 16.6 & $0.78 \mathrm{~s}$ & 16.7 & $0.80 \mathrm{~s}$ & 16.5 \\
\hline 25 & $0.82 \mathrm{~s}$ & 16.4 & $0.82 \mathrm{~s}$ & 16.7 & $0.81 \mathrm{~s}$ & 16.4 \\
\hline 26 & $0.99 \mathrm{~s}$ & 16.1 & $0.98 \mathrm{~s}$ & 16.2 & $0.96 \mathrm{~s}$ & 16.1 \\
\hline 27 & $0.93 \mathrm{~s}$ & 14.7 & $0.91 \mathrm{~s}$ & 14.7 & $0.92 \mathrm{~s}$ & 14.6 \\
\hline 28 & $0.63 \mathrm{~s}$ & 17.8 & $0.70 \mathrm{~s}$ & 17.9 & $0.70 \mathrm{~s}$ & 18.2 \\
\hline 29 & $0.99 \mathrm{~d}(6.5)$ & 22.2 & $0.97 \mathrm{~d}(7.6)$ & 22.1 & $0.96 \mathrm{~d}(6.6)$ & 22.6 \\
\hline \multirow[t]{2}{*}{30} & $4.15 \mathrm{~d}(11.2)$ & 47.6 & $4.14 \mathrm{~d}(11.2)$ & 47.5 & $3.96 \mathrm{~d}(12.6)$ & 72.3 \\
\hline & $3.89 \mathrm{~d}(11.2)$ & & $3.89 \mathrm{~d}(11.6)$ & & $3.72 \mathrm{~d}(12.6)$ & \\
\hline $\mathrm{OH}$ & $3.14 \mathrm{~m}$ & & & & & \\
\hline \multirow[t]{4}{*}{ OAc } & $1.97 \mathrm{~s}$ & 21.4 & $1.97 \mathrm{~s}$ & 21.3 & $1.97 \mathrm{~s}$ & 21.3 \\
\hline & & 171.4 & $1.98 \mathrm{~s}$ & 21.3 & $1.98 \mathrm{~s}$ & 21.3 \\
\hline & & & & 171.1 & & 171.1 \\
\hline & & & & 171.1 & & 171.1 \\
\hline \multirow[t]{2}{*}{ OEt } & & & & & $1.13 \mathrm{t}(6.9)$ & 15.2 \\
\hline & & & & & $3.35 \mathrm{~m}$ & 65.9 \\
\hline
\end{tabular}

${ }^{a} \delta$ in ppm and $J$ (in $\mathrm{Hz}$ ) are in parentheses. Recorded in $\mathrm{CDCl}_{3}$ at $400 \mathrm{MHz}$ and $125 \mathrm{MHz}$ for ${ }^{1} \mathrm{H}$ and ${ }^{13} \mathrm{C}-\mathrm{NMR}$, respectively. ${ }^{*}$ overlapped.

Figure 2. Selected correlations of 1. Double-ended arrows indicate NOESY, and single arrows indicate $\mathrm{HMBC}(\mathrm{C}$ to $\mathrm{H})$ correlations.

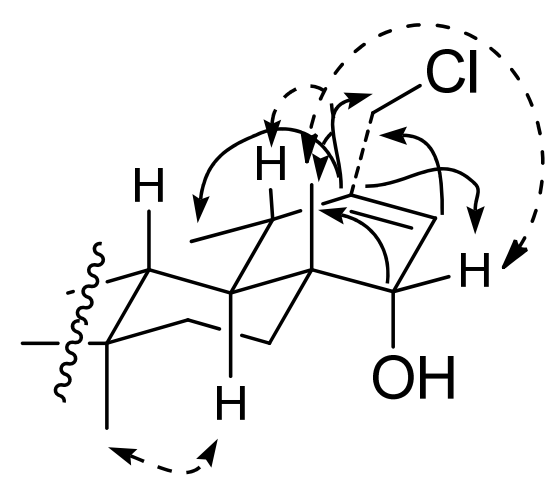

The most important HMBC and NOESY correlations are shown in Figure 1. Treatment of 1 with $\mathrm{Ac}_{2} \mathrm{O}$-pyridine gave a diacetyl derivative 1a for which its HREIMS experiment indicated the molecular formula $\mathrm{C}_{34} \mathrm{H}_{53} \mathrm{O}_{4}{ }^{37} \mathrm{Cl}$ (calcd. for $[\mathrm{M}]^{+}$562.3603; found 562.3624) and $\mathrm{C}_{34} \mathrm{H}_{54} \mathrm{O}_{4}{ }^{35} \mathrm{Cl}$ (calcd. for [M] 560.3654; found 560.3644). The data implied the presence of a double bond between C-20 and C-21, the chloro atom at C-30, and the acetyl group at C-3 and hydroxyl group at C-22. H-22 was assigned in $\beta$-orientation on the basis of the coupling constant with the vinylic proton at $\mathrm{C}-21$ and cross-peak in the NOESY experiment with the $\mathrm{CH}_{3}-28$. From the above findings, the structure of 
30-chloro-3 $\beta$-acetoxy-22 $\alpha$-hydroxyl-20(21)-taraxastene was assigned to $\mathbf{1}$, and it was named chlorotolpidiol. To the best of our knowledge, this is the first example of a pentacyclic triterpene of the taraxastane-ursane series with a chloro functionality.

Compound 2 was obtained as a colourless amorphous solid and its molecular formula was determined by a HRESIMS experiment as $\mathrm{C}_{36} \mathrm{H}_{58} \mathrm{O}_{5}$ (calcd. for $[\mathrm{M}+\mathrm{Na}]^{+}$593.4182; found 593.4176). The IR spectrum revealed the absorption bands for a carbonyl group $\left(1732 \mathrm{~cm}^{-1}\right)$ and double bond $\left(2872 \mathrm{~cm}^{-1}\right)$. The ${ }^{1} \mathrm{H}-\mathrm{NMR}$ spectrum (Table 1) exhibited six singlet methyl groups at $\delta_{\mathrm{H}} 0.70,0.80$, $0.81(6 \mathrm{H}), 0.92$ and 0.96 , a secondary methyl group at $\delta_{\mathrm{H}} 0.96(3 \mathrm{H}, \mathrm{d}, J=6.6 \mathrm{~Hz})$ attributed to C-29, a vinyl proton at $\delta_{\mathrm{H}} 5.75(1 \mathrm{H}, \mathrm{d}, J=6.3 \mathrm{~Hz})$, two acetyl groups at $\delta_{\mathrm{H}} 1.97 \mathrm{~s}$ and $1.98 \mathrm{~s}$, two oxymethine signals at $\delta_{\mathrm{H}} 4.43(1 \mathrm{H}, \mathrm{dd}, J=5.1,10.4 \mathrm{~Hz})$ and $4.55(1 \mathrm{H}, \mathrm{d}, J=6.3 \mathrm{~Hz})$, an oxymethylene signal at $\delta_{\mathrm{H}}$ $3.96(1 \mathrm{H}, \mathrm{d}, J=12.6 \mathrm{~Hz})$ and $3.72(1 \mathrm{H}, \mathrm{d}, J=12.6 \mathrm{~Hz})$ and an ethoxy group at $\delta_{\mathrm{H}} 3.35(2 \mathrm{H}, \mathrm{m})$ and $1.13(3 \mathrm{H}, \mathrm{t}, J=6.9 \mathrm{~Hz})$. The extra acetyl signal at C-22 was observed, since the oxygenated methine proton of 1 at $\delta_{\mathrm{H}} 3.35(1 \mathrm{H}, \mathrm{d}, J=6.6 \mathrm{~Hz})$ was displaced to $\delta_{\mathrm{H}} 4.55(1 \mathrm{H}, \mathrm{d}, J=6.3 \mathrm{~Hz})$ in 2 . Moreover, the halogenated group was replaced by a ethoxyl group at C-30 since the carbon in $\mathbf{2}$ was displaced to low field at $\delta_{\mathrm{C}} 72.3$ (Table 1). The structure of 2 was determined by a combination of COSY, DEPT, HSQC, HMBC, and NOESY experiments. Based on the above data, the new compound tolpidiol A 2 was identified as 3 $\beta, 22 \alpha$-diacetoxy-30-ethoxy-20(21)-taraxastene.

Compound $\mathbf{3}$ was purified as its diacetate $\mathbf{3 a}$ by treatment with acetic anhydride $\left(\mathrm{Ac}_{2} \mathrm{O}\right)$ in pyridine, 3a was isolated as a colourless amorphous solid and its HRESIMS experiment indicated the molecular formula $\mathrm{C}_{34} \mathrm{H}_{54} \mathrm{O}_{6}$ (calcd. for $[\mathrm{M}+\mathrm{Na}]^{+}$581.3818; found 581.3801). The IR spectrum revealed the absorption bands for carbonyl $1728 \mathrm{~cm}^{-1}$, and hydroxyl $3391 \mathrm{~cm}^{-1}$ groups, the presence of these groups was confirmed by the ${ }^{1} \mathrm{H}$ and ${ }^{13} \mathrm{C}-\mathrm{NMR}$ spectra (Table 2). The ${ }^{1} \mathrm{H}-\mathrm{NMR}$ spectrum of $\mathbf{3 a}$ showed signals for five tertiary methyl groups at $\delta_{\mathrm{H}} 0.81(6 \mathrm{H}, \mathrm{br}, \mathrm{s}), 1.00,1.02$ and 1.11 , and two secondary methyl groups at $\delta_{\mathrm{H}} 0.86(3 \mathrm{H}, \mathrm{d}, J=6.4 \mathrm{~Hz})$ and $\delta_{\mathrm{H}} 0.88(3 \mathrm{H}, \mathrm{d}, J=7.3 \mathrm{~Hz})$ suggesting a pentacyclic triterpene with an ursane skeleton. An olefinic proton at $\delta_{\mathrm{H}} 5.30(1 \mathrm{H}, \mathrm{d}, J=3.1 \mathrm{~Hz})$ was assigned to $\mathrm{H}-12$, two oxygenated methines at $\delta_{\mathrm{H}} 4.45(1 \mathrm{H}, \mathrm{dd}, J=3.0,9.6 \mathrm{~Hz})$ and $4.46(1 \mathrm{H}, \mathrm{dd}, J=5.0,9.5 \mathrm{~Hz})$ corresponding to $\mathrm{H}-3$ and $\mathrm{H}-11$ respectively, the latter showing vicinal correlation in the COSY experiment with the olefinic proton $\mathrm{H}-12$, while the proton $\mathrm{H}-9 \delta_{\mathrm{H}} 1.81(1 \mathrm{H}, \mathrm{d}, J=9.5 \mathrm{~Hz})$ indicated the presence of a hydroperoxide at $\mathrm{C}-11$. The presence of an oxygenated methylene was confirmed by the signals at $\delta_{\mathrm{H}} 3.56(1 \mathrm{H}, \mathrm{d}, J=11.0 \mathrm{~Hz})$ and $3.93(1 \mathrm{H}, \mathrm{d}, J=11.0 \mathrm{~Hz})$. The ${ }^{13} \mathrm{C}-\mathrm{NMR}$ (Table 2) and DEPT data indicated the presence of two ester carbonyl groups, nine methyl carbons, nine aliphatic methylenes, two olefinic carbons, and seven methine carbons. Thus, the position of acetyl groups in compound 3a was assigned by a HMBC correlation between the signal at $\delta_{\mathrm{C}} 171.0$ and that at $\delta_{\mathrm{H}} 4.45$; and the signals at $\delta_{\mathrm{C}} 171.3$ and $\delta_{\mathrm{H}} 3.93$. The coupling constant between $\mathrm{H}-9$ and $\mathrm{H}-11(J=9.5 \mathrm{~Hz})$ established the $\alpha$-orientation of the hydroperoxide at C-11. The EI-MS data of 3a showed direct loss of $\mathrm{H}_{2} \mathrm{O} \mathrm{m} / z 540$ and $\mathrm{H}_{2} \mathrm{O}_{2} \mathrm{~m} / z$ 524, confirming the presence of the hydroperoxide.

The structure elucidation and NMR assignments were based primarily on the results of HSQC, $\mathrm{HMBC}$, and COSY experiments which allowed the complete assignment of all $\mathrm{H}$ - and $\mathrm{C}$-atoms, and the NOESY (Figure 3) data provided the configuration of compound 3a. Therefore, the structure of $\mathbf{3}$

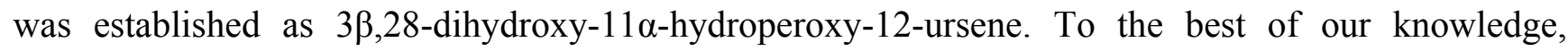
compound 3 is a novel triterpenoid, which we named tolpidiol B. 
Table 2. ${ }^{1} \mathrm{H}$ and ${ }^{13} \mathrm{C}-\mathrm{NMR}$ data for compound $\mathbf{3 a}{ }^{a}$.

\begin{tabular}{|c|c|c|}
\hline Position & $\delta \mathbf{H}$ & $\delta \mathrm{C}$ \\
\hline 1 & $\begin{array}{c}0.85 \mathrm{~m} \\
2.08 \mathrm{dt}(3.5,7.0)\end{array}$ & 39.4 \\
\hline 2 & $1.58 *$ & 23.7 \\
\hline 3 & $4.45 \mathrm{dd}(3.0,9.6)$ & 80.6 \\
\hline 4 & - & 38.0 \\
\hline 5 & $0.88 \mathrm{~m}$ & 55.3 \\
\hline 6 & $\begin{array}{l}1.45 * \\
1.31 *\end{array}$ & 18.1 \\
\hline 7 & $\begin{array}{l}1.45 \mathrm{~m} \\
1.25 \mathrm{~m}\end{array}$ & 33.3 \\
\hline 8 & - & 43.2 \\
\hline 9 & $1.81 \mathrm{~d}(9.5)$ & 48.8 \\
\hline 10 & - & 37.8 \\
\hline 11 & $4.46 \mathrm{dd}(5.0,9.5)$ & 81.6 \\
\hline 12 & $5.30 \mathrm{~d}(3.1)$ & 125.8 \\
\hline 13 & - & 144.5 \\
\hline 14 & - & 42.0 \\
\hline 15 & $\begin{array}{l}1.60 * \\
0.90 \mathrm{~m}\end{array}$ & 26.2 \\
\hline 16 & $\begin{array}{c}1.16^{*} \\
1.92 \operatorname{td}(3.5,9.0)\end{array}$ & 23.3 \\
\hline 17 & - & 36.9 \\
\hline 18 & $1.45 \mathrm{~m}$ & 53.7 \\
\hline 19 & $1.35 \mathrm{~m}$ & 39.0 \\
\hline 20 & $1.28 \mathrm{~m}$ & 39.3 \\
\hline 21 & $1.40 \mathrm{~m}$ & 30.4 \\
\hline 22 & $\begin{array}{c}1.31 \mathrm{~m} \\
1.52 \mathrm{dt}(3.0,6.5)\end{array}$ & 35.5 \\
\hline 23 & $0.81 \mathrm{~s}$ & 28.2 \\
\hline 24 & $0.81 \mathrm{~s}$ & 16.7 \\
\hline 25 & $1.02 \mathrm{~s}$ & 16.8 \\
\hline 26 & $1.00 \mathrm{~s}$ & 18.0 \\
\hline 27 & $1.11 \mathrm{~s}$ & 22.2 \\
\hline 28 & $\begin{array}{l}3.56 \mathrm{~d}(11.0) \\
3.93 \mathrm{~d}(11.0)\end{array}$ & 71.0 \\
\hline 29 & $0.86 \mathrm{~d}(6.4)$ & 17.4 \\
\hline 30 & $0.88 \mathrm{~d}(7.3)$ & 21.3 \\
\hline OAc & $\begin{array}{l}1.97 \mathrm{~s} \\
1.97 \mathrm{~s}\end{array}$ & $\begin{array}{c}21.0 \\
21.3 \\
171.0 \\
171.3\end{array}$ \\
\hline
\end{tabular}

${ }^{a} \delta$ in ppm and $J \overline{\text { (in } \mathrm{Hz} \text { ) are in parentheses. Recorded in } \mathrm{CDCl}_{3} \text { at } 400 \mathrm{MHz}}$ and $125 \mathrm{MHz}$ for ${ }^{1} \mathrm{H}$ - and ${ }^{13} \mathrm{C}-\mathrm{NMR}$, respectively. * overlapped. 
Figure 3. Selected correlations of 3a. Bond bolded indicate COSY, Double-ended arrows indicate NOESY, and single arrows indicate $\operatorname{HMBC}(\mathrm{C}$ to $\mathrm{H})$ correlations.

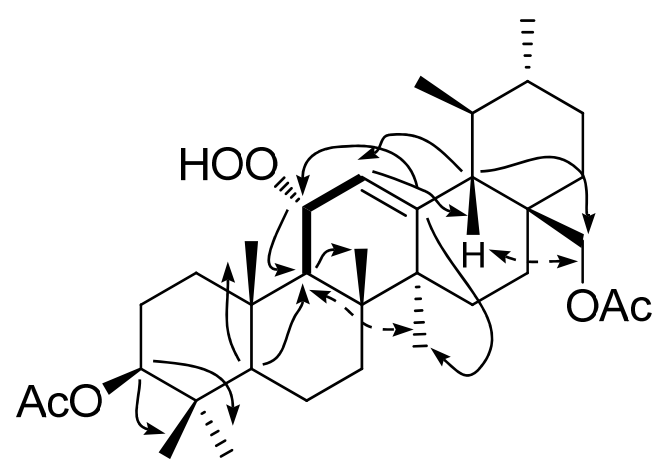

Compound 1 could derive from the known triterpene acetyl-ptiloepoxide 4 [8,9] which was identified by us from $T$. proustii as an inseparable mixture. Triterpenes containing an epoxide at the $\Delta^{21-22}$ position are known and have been isolated before from a Tolpis species [4]. Based on this, we envisioned the formation of compound 1 by chlorination of the double bond, followed by isomerization and $\beta$ opening of the epoxide, and protonation, maintaining the $\alpha$-orientation at the C-22 observed in the precursor compound acetyl-ptiloepoxide (Figure 4).

Figure 4. Tentative forming process of compound 1.

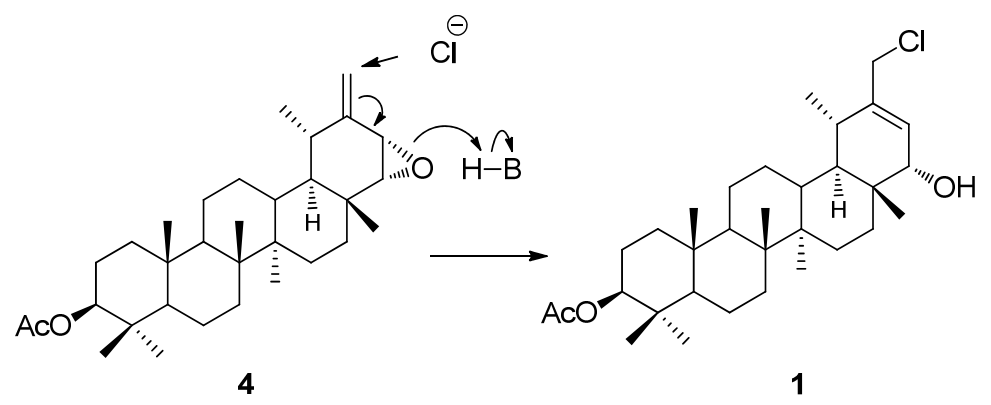

Although the number is relatively small, several halogenated triterpenes and other higher terpenes have been described mainly from marine sources [10]. However, the presence of chlorinated triterpenoids in terrestrial plants is very rare and just few cases have been reported [11-14]. Initially, compound 1 seemed to be an artifact of the isolation process, but Chen et al. [14] proved that to obtain chlorinated compounds, a chlorine source such as $\mathrm{CHCl}_{3}$ with $\mathrm{HCl}$ is necessary. During the isolation process, no chlorinated solvents were used (see Experimental). In the chromatographic separation, dichloromethane was used in the preparative TLC, which was not enough to interact with the possible precursor (ptiloepoxide) of 1. Compound $\mathbf{2}$ was isolated as a presumed artifact; this compound was probably obtained from $\mathbf{1}$, by a nucleophilic substitution reaction due to the use of hot EtOH during the extraction process.

Additionally, from $T$. proustii 15 known compounds were isolated, including aromatic compounds: scopoletin [15] aesculetin [15] and apigenin [16]; the diterpene phytene-1,2-diol [17] and the triterpenoids stigmasterol [18], ergosterol peroxide [19], ursolic acid [20], lupan-20(29)-ene-3 $\beta, 30$ diol [21], 21 $\alpha$-hydroxytaraxasterol [22], 11-oxo- $\beta$-amyrin [23], 3 $\beta$-acetoxy-urs-12-ene-1 $\beta, 11 \alpha$-diol [24],

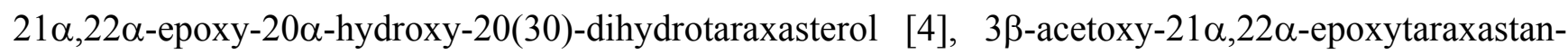
$20 \alpha$-ol [25], 22-oxo-20-taraxasten-3 $\beta$-ol [9], $\beta$-amyrin [26]. From T. lagopoda seven known 
compounds were isolated, including aromatic compounds: 2,4'-dihydroxy-4-methoxybenzophenone [4] and triterpenoids: stigmasterol [18], ergosterol peroxide [19], a mixture of 7-oxo- $\beta$-sitosterol and 7-oxo-stigmasterol [26,27], ursolic acid [20], and $\alpha$-amyrin [28]. Their structures were confirmed by comparison of their spectral data with those reported in the literature.

\subsection{Antioxidant Activities}

Natural antioxidants that are present in plants are responsible for inhibiting or preventing the deleterious consequences of oxidative stress. In Table 3 the relative antioxidant efficiency of both Tolpis extracts against the DPPH radical is shown. Antioxidants suppress the absorbance at $515 \mathrm{~nm}$ on a time scale dependent on the antioxidant activity of extracts. The RSA of the crude extract of T. proustii (59.6\%) was higher than that of T. lagopoda (41.4\%). FRAP assay was used to study the ability of the antioxidants in the extracts to reduce ferric iron to the ferrous form. The same behaviour as for the DPPH assay was observed, T. lagopoda being less active than T. proustii $(4.1$ and $18.1 \mu \mathrm{mol}$ of $\mathrm{Fe}$ (III) reduced to $\mathrm{Fe}$ (II) per gram of dry plant respectively) (Table 3). On the other hand, the free radical scavenging and ferric reducing power assays revealed that aesculetin (isolated from T. proustii) showed the highest antioxidant activities as compared with those of $\alpha$-tocopherol and BHA (Table 4). Aesculetin gave a RSA value of $100 \%$ with a $\mathrm{t}_{1 / 2}$ (time required for $50 \%$ scavenging of DPPH radical in the specified concentration of antioxidant) of 22.5 seconds, while BHA and $\alpha$-tocopherol showed RSA of 21.9 and $17.7 \%$ respectively after $20 \mathrm{~min}$. Aesculetin (at concentration $0.1 \mathrm{mg} \mathrm{mL}^{-1}$ ) showed also higher antioxidant activities than both extracts (at concentration $10 \mathrm{mg} \mathrm{mL}^{-1}$ ), because the extracts are complex mixtures that include active components at lower levels. Moreover, the crude extracts tend to have more interfering substances that may interact with the antioxidants, decreasing their effectiveness. The antioxidant activities found in this study indicated that aesculetin, as well as both extracts, are ideal for use in the health food industry. Because of the high content of aesculetin found in the T. proustii extract $(566.8 \mathrm{mg})$, this extract may be considered to be a natural source of aesculetin with diverse potential therapeutic uses.

Table 3. Antioxidant activity of crude extracts derived from T. proustii and T. lagopoda.

\begin{tabular}{lcc}
\hline Assays & T. proustii & T. lagopoda \\
\hline RSA $^{\mathrm{a}}$ & $59.6 \pm 0.4$ & $41.4 \pm 0.1$ \\
FRAP $^{\mathrm{b}}$ & $18.1 \pm 0.4$ & $4.1 \pm 0.2$ \\
FRAP $^{\mathrm{c}}$ & $93 \pm 2$ & $41 \pm 1$ \\
\hline
\end{tabular}

a $\%$ inhibition \pm standard deviation of three measurements. ${ }^{\mathrm{b}} \mu \mathrm{mol}$ of $\mathrm{Fe}(\mathrm{III})$ reduced to $\mathrm{Fe}(\mathrm{II})$ per gram of dry plant \pm standard deviation of three measurements. ${ }^{c} \mu$ mol of $\mathrm{Fe}$ (III) reduced to $\mathrm{Fe}$ (II) per gram of ethanolic residue \pm standard deviation of three measurements.

Table 4. Antioxidant activity of aesculetin, $\alpha$-tocopherol and butylated hydroxyanisol (BHA).

\begin{tabular}{cccc}
\hline Assays & $\begin{array}{c}\text { Aesculetin } \\
\mathbf{0 . 1} \mathbf{~ m g ~ m L}^{-1}\end{array}$ & $\begin{array}{c}\boldsymbol{\alpha} \text {-Tocopherol } \\
\mathbf{0 . 1} \mathbf{~ m g ~ m L}^{\mathbf{- 1}}\end{array}$ & $\begin{array}{c}\text { BHA } \\
\text { 0.1 } \mathbf{~ m g ~ m L}^{-\mathbf{1}}\end{array}$ \\
\hline DPPH $^{\mathrm{a}}$ & $100 \pm 0$ & $17.7 \pm 0.1$ & $21.9 \pm 0.6$ \\
FRAP $^{\mathrm{b}}$ & $9.4 \pm 0.7$ & $0.97 \pm 0.03$ & $3.13 \pm 0.05$ \\
\hline
\end{tabular}

a $\%$ inhibition \pm standard deviation of three measurements. ${ }^{b} \mu$ mol of Fe(III) reduced to Fe(II) per mg of compound \pm standard deviation of three measurements. 


\subsection{Cytotoxic Activity}

K-562 and K-562/ADR cells which are sensitive or resistant to doxorubicin, respectively, were incubated with the compounds shown in Table 5 to evaluate their potential cytotoxicity. After $72 \mathrm{~h}$, cell survival was determined by the MTT assay and the $\mathrm{IC}_{50}$ values are summarized in Table 5 . Among the different compounds ursolic acid and 22-oxo-20-taraxasten-3 $\beta$-ol exhibit the strongest effects in mitochondrial reduction of tetrazolium salts to formazan, while the ursolic derivatives and the 1,2-diacetoxyphytene exhibit the weakest effects. Furthermore, K-562 and K-562/ADR cells exhibit comparable sensitivity to compounds ursolic acid and 22-oxo-20-taraxasten-3 $\beta$-ol (Table 5). These results suggest that the overexpression of the drug efflux protein, P-glycoprotein does not confer resistance against these compounds.

Table 5. Effects of some compounds and derivatives isolated from T. proustii and T. lagopoda on the growth of the human leukemia cell lines.

\begin{tabular}{c|cc}
\hline \multirow{2}{*}{ Compound } & \multicolumn{2}{|c}{$\mathbf{I C}_{\mathbf{5 0}}(\boldsymbol{\mu M})$} \\
& K562 & K562/ADR \\
\hline Ursolic acid & $40.6 \pm 3.6$ & $49.2 \pm 3.1$ \\
Ursolic acid methyl ester & $59.3 \pm 15.5$ & $64.0 \pm 14.5$ \\
Acetyl ursolic acid & $99.5 \pm 20.5$ & $>100$ \\
Acetyl ursolic acid methyl ester & $>100$ & $>100$ \\
Aesculetin & $63.2 \pm 3.2$ & $77.0 \pm 5.1$ \\
Aesculetin acetyl & $68.6 \pm 17.1$ & $70.3 \pm 19.2$ \\
Aesculetin diacetyl & $62.3 \pm 6.6$ & $59.5 \pm 4.5$ \\
11-Oxo- $\beta$-amyrin & $>100$ & $>100$ \\
22-Oxo-20-taraxasten-3 $\beta-o l$ & $30.0 \pm 10.0$ & $43.0 \pm 7.0$ \\
1,2-Diacetoxyphytene & $>100$ & $>100$ \\
\hline
\end{tabular}

Cells were cultured for $72 \mathrm{~h}$ and the $\mathrm{IC}_{50}$ values were calculated as described in the Experimental section. The data shown represent the means \pm SEM of 3-5 independent experiments with three determinations in each.

\section{Experimental}

\subsection{General Experimental Procedures}

Optical rotations: Perkin-Elmer model 343 polarimeter. IR Spectra: Bruker model IFS-55 spectrophotometer. ${ }^{1} \mathrm{H}$ and ${ }^{13} \mathrm{C}-\mathrm{NMR}$ spectra: Bruker model AMX-500 and AMX-400 spectrometers with standard pulse sequences, operating at 500 and $400 \mathrm{MHz}$ for ${ }^{1} \mathrm{H}-$, and $125 \mathrm{MHz}$ for ${ }^{13} \mathrm{C}-\mathrm{NMR}$, $\mathrm{CDCl}_{3}$ was used as solvent and TMS as internal standard. EI-MS: Micromass model Autospec (70 eV) spectrometer. The constituents of the ethanolic extracts were separated by gravity column chromatography, medium pressure liquid chromatography (MPLC) and preparative TLC. Column chromatography (CC): silica gel $\mathrm{SiO}_{2}$; (70-230 mesh, Merck), column fractions were monitored by TLC (silica gel $60 F_{254}$ ), Medium pressure column chromatography (MPLC): silica gel Merck $(40-63 \mu \mathrm{m})$. Prep. TLC: silica gel $60 P F_{254}+366$ plates $(20 \times 20 \mathrm{~cm}, 1-\mathrm{mm}$ thickness $)$. 


\subsection{Plant Material}

The plant material was identified by Dr. Rosa Febles. T. proustii was collected at Roque Agando (La Gomera, Canary Islands) in May 2009. A voucher specimen has been deposited at the Herbarium of the Viera y Clavijo Botanical Garden in Las Palmas de Gran Canaria (LPA 24194). T. lagopoda was collected at Tenteniguada (Gran Canaria, Canary Islands) in May 2008. A voucher specimen has been deposited at the Herbarium of the Viera y Clavijo Botanical Garden in Las Palmas de Gran Canaria (LPA 23596).

\subsection{Extraction and Isolation}

The aerial parts of $T$. proustii $(3.0 \mathrm{Kg})$ were extracted with ethanol $(4 \mathrm{~L})$ in a Soxhlet until exhaustion. Solvent removal afforded a viscous residue $(541.5 \mathrm{~g})$ which was fractionated by means of $\mathrm{CC}\left(\mathrm{SiO}_{2}\right.$; hexane/AcOEt step gradients). The fractions eluted with hexane-AcOEt (7:3) were submitted to a new MPLC chromatography with hexane-AcOEt (9:1), to give stigmasterol (30.6 mg); $3 \beta$-acetoxy-21 $\alpha, 22 \alpha$-epoxy-20 $\alpha$-hydroxy-20(30)-dihydrotaraxasterol (6.3 $\mathrm{mg}$ ), obtained by preparative TLC (benzene-ethyl acetate 8:2); ergosterol peroxide (obtained as its acetylated derivative upon acetylation of one of the obtained fractions $(2.3 \mathrm{mg}) ; 3 \beta, 30$-dihydroxylup-20(29)-ene (31.1 $\mathrm{mg})$; phytene-1,2-diol (7.6 mg); 3a (2.3 mg), isolated by successive preparative TLCs (benzene-AcOEt, 9.9:0.1, 2 elutions; dichloromethane-hexane 1:1, 3 elutions) and 1 (3.7 $\mathrm{mg})$, obtained by preparative TLC (dichloromethane, 3 elutions). Subsequent chromatography by MPLC with hexane-AcOEt (8.5:1.5) gave ursolic acid (193.8 $\mathrm{mg}) ; 21 \alpha$-hydroxytaraxasterol $(8,9 \mathrm{mg})$, obtained by preparative TLC (benzene-AcOEt, 8.5:1.5, 4 elutions); 11 -oxo- $\beta$-amyryn (15.4 mg); 22-oxo-taraxasten-3 $\beta$-ol (2.7 mg) isolated by preparative TLC (dichloromethane-AcOEt 9:1, 4 elutions); $\beta$-amyryn (5.2 mg); and 2 $(2.1 \mathrm{mg})$, obtained upon crystallization in hexane-AcOEt and subsequent purification by preparative TLC (dichloromethane-AcOEt 8:2).

The fractions eluted with hexane-AcOEt (3:2) were partially rechromatographed by MPLC in hexane-AcOEt (7:3) giving, after preparative TLC (benzene-AcOEt, 8:2, 2 elutions), apigenin $(41.2 \mathrm{mg})$ and scopoletin $(6.7 \mathrm{mg})$. The remainder of these fractions was submitted to subsequent rechromatography by MPLC in hexane-AcOEt (8.5:1.5) to give $3 \beta$-acetoxy-1 $\beta, 11 \alpha$-dihydroxy-urs-12ene $(9.7 \mathrm{mg}$ ), isolated by preparative TLC (benzene-AcOEt, 8:2, 4 elutions), and $21 \alpha, 22 \alpha$-epoxy-20 $\alpha$ hydroxy-20(30)-dihydrotaraxasterol $(3.6 \mathrm{mg}$ ), purified by preparative TLC (hexane-AcOEt, 8:2, 2 elutions). Finally, the fractions eluted with hexane-AcOEt (1:1) afforded aesculetin (566.8 mg), upon crystallization in hexane-AcOEt.

The aerial parts of $T$. lagopoda $(2.7 \mathrm{Kg})$ were extracted with ethanol $(4 \mathrm{~L})$ in a Soxhlet until exhaustion. Removal of the solvent afforded a viscous residue $(279.8 \mathrm{~g})$, which was fractionated by $\mathrm{CC}\left(\mathrm{SiO}_{2}\right.$; hexane/AcOEt step gradients). Fractions eluted with hexane-ethyl acetate (4:1) were subsequently chromatographed by MPLC with hexane-ethyl acetate (7.5:2.5) to give five fractions (numbered from fraction 1 to 5). From fraction 1 stigmasterol $(14.3 \mathrm{mg}$ ) was purified by crystallization in hexane-AcOEt, while fraction 3 afforded 2,4'-dihydroxy-4-methoxybenzophenone, obtained by crystallization with hexane-AcOEt $(15.1 \mathrm{mg})$ and from its mother liquors $\alpha$-amyrin $(2.9 \mathrm{mg})$ was obtained by preparative TLC with (benzene-AcOEt, 9:1, 5 elutions), as its acetylated derivative, after 
acetylation. From fraction 4 ursolic acid $(6.1 \mathrm{mg})$ was purified after a methylation process. Fraction 5 afforded ergosterol peroxide (11 mg) by preparative TLC (hexane-AcOEt, 9:1, 2 elutions), purified after acetylation as its acetyl derivative. Finally, fraction 2 afforded compound 2 (1.8 $\mathrm{mg})$ by preparative TLC (benzene-AcOEt, 9:1). Fractions eluted with hexane-AcOEt (7:3) were subsequently chromatographed by MPLC with hexane-AcOEt (8:2), the most polar fractions affording the mixture of 7-oxo- $\beta$-sitosterol and 7-oxo-stigmasterol $(18.1 \mathrm{mg})$ were purified by preparative TLC (hexaneAcOEt, 7:3, 5 elutions).

30-Chloro-3 $\beta$-acetoxy-22 $\alpha$-hydroxyl-20(21)-taraxastene (1). Amorphous white solid; $[\alpha]_{D}^{25}=+6.0$ $\left(\mathrm{CHCl}_{3}, \mathrm{c}\right.$ 0.001); for ${ }^{1} \mathrm{H}$ and ${ }^{13} \mathrm{C}-\mathrm{NMR}$ data, see Table 1. IR, $v$ max $(\mathrm{KBr}): 3446,2924,2853,1732$, 1439, 1244, $1172 \mathrm{~cm}^{-1}$. EIMS m/z 520 (5.7), 518 (15.5), 502 (13.5), 500 (35.2), 483 (7.3), 460 (4.3), 458 (10.5), 464 (13.6), 404 (5.1) 249 (21.0), 190 (36.5) 189 (100.0), 187(40.0) 161 (17.0), 133(29.0) 121 (36.0), 81(31.6). HREIMS $m / z 520.3497[\mathrm{M}]^{+}$(calcd for $\left.\mathrm{C}_{32} \mathrm{H}_{51} \mathrm{O}_{3}{ }^{37} \mathrm{Cl} 520.3497\right), 518.3517$ [M] ${ }^{+}$ (calcd for $\mathrm{C}_{32} \mathrm{H}_{51} \mathrm{O}_{3}{ }^{35} \mathrm{Cl}$ 518.3527), 502.3414) $\left[\mathrm{M}-\mathrm{H}_{2} \mathrm{O}\right]^{+}$(calcd for $\mathrm{C}_{32} \mathrm{H}_{49} \mathrm{O}_{2}{ }^{37} \mathrm{Cl}$ 502.3392), 500.3436 $\left[\mathrm{M}-\mathrm{H}_{2} \mathrm{O}\right]^{+}$(calcd for $\mathrm{C}_{32} \mathrm{H}_{49} \mathrm{O}_{2}{ }^{35} \mathrm{Cl} 500.3421$.

Acetylation of 1 . Compound $\mathbf{1}(2.0 \mathrm{mg})$ was dissolved in pyridine $(1 \mathrm{~mL})$ and acetic anhydride $(2 \mathrm{~mL})$, and the reaction was further stirred at room temperature for $12 \mathrm{~h}$ and after usual work-up. The product was dried under vacuum to furnish $1 \mathrm{a}(1.8 \mathrm{mg})$. For ${ }^{1} \mathrm{H}$ and ${ }^{13} \mathrm{C}$-NMR spectroscopic data, see Table 1 .

30-Chloro-3 $\beta, 22 \alpha$-diacetoxy-20(21)-taraxastene (1a). Amorphous white solid; $[\alpha]_{D}^{25}=+86.7\left(\mathrm{CHCl}_{3}\right.$, c $4.5 \times 10^{-3}$ ); for ${ }^{1} \mathrm{H}$ and ${ }^{13} \mathrm{C}-\mathrm{NMR}$ data, see Table 1. IR, $v$ max $(\mathrm{KBr}): 2920,2852,1731,1652,1540$, 1456, 1372, 1247, 1016, $982 \mathrm{~cm}^{-1}$. EIMS m/z 562 (0.7), 560 (1.7), 525 (34.7), 500 (27.0), 466 (10.4), 404 (6.4), 189 (100), 95 (52.8), 69 (56). HREIMS m/z 562.3624 [M] (calcd for $\mathrm{C}_{34} \mathrm{H}_{53} \mathrm{O}_{4}{ }^{37} \mathrm{Cl} 562.3603$ ), $560.3644[\mathrm{M}]^{+}$(calcd for $\mathrm{C}_{34} \mathrm{H}_{53} \mathrm{O}_{4}{ }^{35} \mathrm{Cl} 560.3632$ ).

$3 \beta, 22 \alpha$-Diacetoxy-30-ethoxy-20(21)-taraxastene (2). Colourless amorphous solid; $[\alpha]_{D}^{25}=+4.8\left(\mathrm{CHCl}_{3}\right.$, c 0.015); for ${ }^{1} \mathrm{H}$ and ${ }^{13} \mathrm{C}-\mathrm{NMR}$ data, see Table 1. IR, $v$ max (KBr): 2931, 2872, 1732, 1652, 1464, 1456, $1671,1244,1016 \mathrm{~cm}^{-1}$. EIMS $\mathrm{m} / z 510(100)[\mathrm{M}-\mathrm{OAc}]^{+}, 450(40)$ [M-2OAc] ${ }^{+}$. HRESIMS positive ion $m / z 593.4176[\mathrm{M}+\mathrm{Na}]^{+}$(Calcd. for $\mathrm{C}_{36} \mathrm{H}_{58} \mathrm{O}_{5} \mathrm{Na}, 593.4182$ ).

33,28-Diacetoxy-11 $\alpha$-hydroperoxy-12-ursene 3a. Colourless amorphous solid; $[\alpha]_{D}^{25}=+9.5\left(\mathrm{CHCl}_{3}, \mathrm{c}\right.$ 0.014); for ${ }^{1} \mathrm{H}$ and ${ }^{13} \mathrm{C}$-NMR data, see Table 2. IR, $v$ max (KBr): 3391, 2951, 2925, 2875, 1728, 1392 , 1244, 1032, 983, $903 \mathrm{~cm}^{-1}$. HREIMS $m / z 540.3829\left[\mathrm{M}-\mathrm{H}_{2} \mathrm{O}\right]^{+}$(Calcd. for $\left.\mathrm{C}_{34} \mathrm{H}_{52} \mathrm{O}_{5}, 540.3815\right) ; \mathrm{m} / \mathrm{z}$ $524.3873\left[\mathrm{M}-\mathrm{H}_{2} \mathrm{O}_{2}\right]^{+}$(Calcd. for $\left.\mathrm{C}_{34} \mathrm{H}_{52} \mathrm{O}_{4}, 524.3866\right)$. HRESIMS positive ion $\mathrm{m} / z$ 581.3801 [M+Na] ${ }^{+}$ (Calcd. for $\mathrm{C}_{34} \mathrm{H}_{54} \mathrm{O}_{6} \mathrm{Na}, 581.3818$ ).

\subsection{Antioxidant Experiments}

\subsubsection{Chemicals}

Methanol HPLC grade (Panreac, Barcelona, Spain) and Milli-Q water (18MQ, Millipore, Billerica, MA, USA) were always used in this study. Formic acid and sodium acetate (Merck, Darmstadt, Germany) were analytical quality reagents. 1,1-Diphenyl-2-picrylhydrazyl (DPPH) and 2,4,6-tri (2- 
pyridyl)-1,3,5-triazine (TPTZ) were purchased from Sigma-Aldrich Chemie (Steinheim, Germany); rutin and gentisic and caffeic acids were supplied by Merck. Ferric chloride $\left(\mathrm{FeCl}_{3} \cdot 6 \mathrm{H}_{2} \mathrm{O}\right)$, ferrous sulphate $\left(\mathrm{FeSO}_{4} \cdot 7 \mathrm{H}_{2} \mathrm{O}\right)$ and glacial acetic acid were obtained from Panreac.

\subsubsection{Preparation of Extracts for Antioxidant Assays}

The ethanolic extract residue was solved in methanol by stirring at room temperature. After centrifugation at 7,000 rpm for $10 \mathrm{~min}$, the supernatant was collected and the antioxidant activity was measured. Aesculetin, $\alpha$-tocopherol and BHA (5 mg) were dissolved in methanol (10 mL). The solution was diluted to $0.1 \mathrm{mg} \mathrm{mL}^{-1}$ to be used for antioxidant assays.

\subsubsection{Free Radical Scavenging Activity on DPPH}

The reducing ability of antioxidants towards DPPH radical was evaluated by measuring the loss of 1,1-diphenyl-2-picrylhydrazyl (DPPH) colour at $515 \mathrm{~nm}$ after reaction with test extracts [29]. The sample solution $(30 \mu \mathrm{L})$ was rapidly mixed with $1 \mathrm{~mL}$ of a $0.1 \mathrm{mM}$ DPPH solution. After $25 \mathrm{~min}$ incubation time in the dark at ambient temperature $\left(23{ }^{\circ} \mathrm{C}\right)$, the decline in absorbance against a methanol blank was recorded. The inhibition percentage values were calculated by equation: Radical Scavenging Activity $(\mathrm{RSA})=100(1-\mathrm{Abs}$ in the presence of sample/Abs in the absence of sample).

\subsubsection{Ferric Reducing Antioxidant Power Assay (FRAP)}

Reducing power was determined according to [30]. This method is based on the reduction of $\mathrm{Fe}^{3+}$ to $\mathrm{Fe}^{2+}$, which is recorded by measuring the formation of a blue colored $\mathrm{Fe}^{2+}$-tripyridyltriazine compound from the colourless oxidized $\mathrm{Fe}^{3+}$ form by the action of electron donating antioxidants. The FRAP reagent consists of $300 \mathrm{mM}$ acetate buffer $(3.1 \mathrm{~g}$ sodium acetate $+16 \mathrm{~mL}$ glacial acetic acid, made up to 1 litre with distilled water; $\mathrm{pH}=3.6$ ), $10 \mathrm{mM}$ TPTZ in $40 \mathrm{mM} \mathrm{HCl}$ and $20 \mathrm{mM} \mathrm{FeCl}{ }_{3} \cdot 6 \mathrm{H}_{2} \mathrm{O}$ in the ratio of $10: 1: 1$.

Extract $(10 \mu \mathrm{L})$ was added to $1.0 \mathrm{~mL}$ freshly prepared and prewarmed $\left(37^{\circ} \mathrm{C}\right)$ FRAP reagent. The mixture was incubated at $37^{\circ} \mathrm{C}$ for $10 \mathrm{~min}$ and the absorbance was measured against a reagent blank $\left(1.0 \mathrm{~mL}\right.$ FRAP reagent $+10 \mu \mathrm{L}$ distilled water) at $593 \mathrm{~nm}$. A standard curve of $\mathrm{Fe}^{2+}$ was constructed over the concentration range of $0.2 \mu \mathrm{mol} \mathrm{L} \mathrm{L}^{-1}$ to $1 \mu \mathrm{mol} \mathrm{L} \mathrm{L}^{-1}$. The results were determined by the regression equation of the curve $(y=0.00221 x+0.00999, r=0.9969)$ and expressed as $\mu$ mol ferric ions reduced to ferrous form per $g$ of dry plant material.

\subsection{Cytotoxic Experiments}

\subsubsection{Cell Culture}

Human leukemia K-562 cells (DSMZ No: ACC 10, German Collection of Microorganisms and Cell Cultures, Braunschweig, Germany) were cultured in RPMI 1640 containing $2 \mathrm{mM}$ L-glutamine supplemented with 10\% (v/v) heat-inactivated fetal bovine serum. The K-562/ADR cell line was kindly provided by Professor Lisa Oliver (INSERM, Nantes, France) and cultured as above. 


\subsubsection{Assay for Growth Inhibition and Cell Viability}

The cytotoxicity of compounds was assessed using a 3-(4,5-dimethylthiazol-2-yl]-2,5-diphenyl-2Htetrazolium bromide (MTT) assay. Briefly, $1 \times 10^{4}$ exponentially growing cells were seeded in 96-well microculture plates with various compounds concentrations $(3-100 \mu \mathrm{M})$ in a volume of $200 \mu \mathrm{L}$. DMSO concentration was the same in all the treatments and did not exceed $0.1 \%(\mathrm{v} / \mathrm{v})$. After $72 \mathrm{~h}$, surviving cells were detected based on their ability to metabolize 3-(4,5-dimethylthiazol-2-yl)-2,5diphenyl- $2 \mathrm{H}$-tetrazolium bromide into formazan crystals. Optical density was read with an ELISA reader at a wavelength of $570 \mathrm{~nm}$ and was used as a measure of cell viability. The MTT dye reduction assay measures mitochondrial respiratory function and can detect the onset of cell death earlier than dye-exclusion methods. Cell survival was calculated as the fraction of cells alive relative to control for each point: cell survival $(\%)=$ mean absorbance in treated cells/mean absorbance in control wells $\times$ 100. Concentrations inducing a $50 \%$ inhibition of cell growth $\left(\mathrm{IC}_{50}\right)$ were determined graphically using the curve fitting algorithm of the computer software Prism 4.0 (GraphPad). Values are means \pm SEM from three independent experiments, each performed in triplicate.

\section{Conclusions}

We have studied two endemic Canary plants of the Tolpis genus and two new compounds tolpidiol A (2) and B (3) and a novel chloro derivative chlorotolpidiol (1) were isolated from T. proustii and T. lagopoda. The isolation of halogenated triterpenoids from terrestrial sources is very rare, and few cases have been reported. To the best of our knowledge, chlorotolpidiol is the first example of a pentacyclic triterpene of the taraxastane-ursane series chlorinated at the position C-30. Herein we present a tentative explanation of the biogenesis of this class of compounds. The presence of chlorine atoms provides chemically addressable handles for further work in organic-medicinal chemistry. The antioxidant activities of the ethanolic extract were evaluated and it showed relative efficiency. We found weak cytotoxic activity against K562 and K-562/ADR cell lines of some of the isolated and derivative compounds.

\section{Acknowledgments}

This work was supported by a Grant from the Ministry of Science of Spain and Innovation and from the European Regional Development Fund (SAF2010-21380) to F.E, Instituto Canario de Investigación del Cáncer to F.L. and Agencia Canaria de Investigación, Innovación y Sociedad de la Información (FEDER) (C200801000174) to J.T. F.L. was supported by JAE-doctoral Program from the Ministerio de Ciencia e Innovación.

\section{References}

1. Kunkel, G.; Beltrán, E.; Bañares, A.J.; Gil, M.C.; González, M.N.; González, J.M.; Haroun, R.J.; Hernández, C.; Losada, A.; Marrero, A.; Rodríguez, J.L.; Rodrigo, J. Flora del Archipiélago Canario (in Spanish). In Tratado florístico, primera parte; Editora Regional Canaria: Las Palmas de Gran Canaria, Spain, 1992. 
2. Archibald, J.K.; Crawford, D.J.; Santos-Guerra, A.; Mort, M.E. The utility of automated analysis of inter-simple sequence repeat (ISSR) loci for resolving relationships in the Canary Islands species of Tolpis (Asteraceae). Am. J. Bot. 2006, 93, 1154-1162.

3. Crawford, D.J.; Archibald, J.K.; Santos-Guerra, A.; Mort, M.E. Allozyme diversity within and divergente among species of Tolpis (Asteraceae Lactuceae) in the Canary Islands: Systematic, Evolutionary and Biogeographical implications. Am. J. Bot. 2006, 93, 656-664.

4. Triana, J.; López, M.; Pérez, F.J.; González-Platas, J.; Estévez, F.; León, F.; Hernández, J.C.; Brouard, I.; Bermejo, J. Chemical constituenst of Tolpis species. Fitoterapia 2009, 80, 437-441.

5. Southon, S. Increased fruit and vegetable consumption within the EU: Potential health benefits. Food Res. Int. 2000, 33, 211-217.

6. Gottesman, M.M.; Fojo, T.; Bates, S.E. Multidrug resistance in cancer: Role of ATP-dependent transporters. Nat. Rev. Cancer 2002, 2, 48-58.

7. Chiang, Y.M.; Kuo, Y.H. Taraxastane type triterpenes from the aerial roots of Ficus microcarpa. J. Nat. Prod. 2000, 63, 898-901.

8. Menichini, F.; Di-Benedetto, R.; Delle-Monache, F. A triterpene epoxide and a guainolide from Ptilostemmon gnaphaloides. Phytochemistry 1996, 41, 1377-1379.

9. Kuo, Y.H.; Chaiang, Y.M. Five new taraxastane-type triterpenes from the aerial roots of Ficus microcarpa. Chem. Pharm. Bull. 1999, 47, 498-500.

10. Gribble, G.W. Naturally Occurring Organohalogen Compounds-A Comprehensive Update, Progress in the Chemistry Of Organic Natural Products; Springer-Verlag: Wien, Austria, 2010; p. 577.

11. Monte, F.J.Q.; Kintzinger, J.P.; Braz-Filho, R. Total assignment of ${ }^{1} \mathrm{H}$ and ${ }^{13} \mathrm{C}$ spectra of the

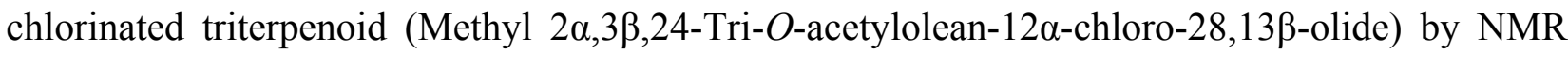
spectroscopy. Magn. Reson. Chem. 1998, 36, 381-384.

12. Luo, X.D.; Wu, S.H.; Ma, Y.B.; Wu, D.G. Dammarane triterpenoids from Amoora yunnanensis. Heterocycles 2000, 53, 2795-2802.

13. Xu, Y.X.; Xiang, Z.B.; Jin, Y.S.; Shen, Y.; Chen, H.S. Two new triterpenoids from the roots of Actinidia chinensis. Fitoterapia 2010, 81, 920-924.

14. Chen, S.N.; Lankin, D.C.; Nikolic, D.; Fabricant, D.S. Lu, Z.Z.; Ramirez, B.; van Breemen, R.B.; Fong, H.H.S.; Farnsworth, N.R.; Pauli, G.F. Chlorination diversifies Cimicifuga racemosa triterpene glycoside. J. Nat. Prod. 2007, 70, 1016-1023.

15. Thuong, P.T.; Hung, T.M.; Ngoc, T.M.; Ha, D.T.; Min, B.S.; Kwack, S.J.; Kang, T.S.; Choi, J.S.; Bae, K. Antioxidant activities of coumarins from Korean medicinal plants and their structureactivity relationships. Phytother. Res. 2010, 24, 101-106.

16. Van-Loo, P.; De-Bruyn, A.; Budesinsky, M. Reinvestigation of the structural assignment of signals in the proton and carbon NMR spectra of the flavone apigenin. Magn. Reson. Chem. 1986, $24,879-882$.

17. Brown, G.D.; Liang, G.Y.; Sy, L.K. Terpenoids from the seeds of Artemisia annua. Phytochemistry 2003, 64, 303-323.

18. Kojima, H.; Sato, N.; Hatano, A.; Ogura, H. Constituents of the labiatae plants. Part 5. Sterol glucosides from Prunella vulgaris. Phytochemistry 1990, 29, 2351-2355.

19. González, A.G.; Bermejo, J.; Rodríguez, E.M.; Hernández, C.E. Chemical constituents of the lichen Ramalina hierrensis. Planta Med. 1992, 58, 214-218. 
20. Seebacher, W.; Simic, N.; Weis, R.; Saf, R.; Kunert, O. Complete assignments of ${ }^{1} \mathrm{H}$ and

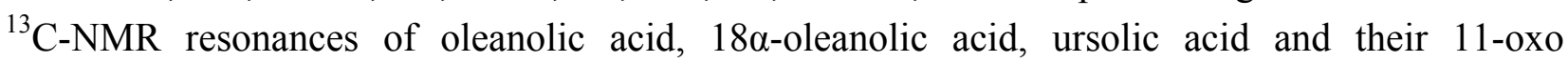
derivatives. Magn. Reson. Chem. 2003, 41, 636-638.

21. Burns, D.; Reynolds, W.F.; Buchanan, G.; Reese, P.B.; Enriquez, R.G. Assignment of ${ }^{1} \mathrm{H}$ and ${ }^{13} \mathrm{C}$ spectra and investigation of hindered side-chain rotation in lupeol derivatives. Magn. Reson. Chem. 2000, 38, 488-493.

22. Petrovic, S.D.; Gorunovic, M.S.; Wray, V.; Merfort, I. A taraxasterol derivative and phenolic compounds from Hieracium gymnocephalum. Phytochemistry 1999, 50, $293-296$.

23. Kapoor, V.K.; Chawla, A.S.; Gupta, Y.C.; Passannanti, S.; Paternostro, M.P. Constituents of Buddleia species leaves. Fitoterapia 1981, 52, 235-237.

24. Öksuz, S.; Ulubelen, A.; Barla, A.; Kohlbau, H.J.; Voelter, W. Triterpenoids and a Diterpene from Euphorbia iberica. Planta Med. 1999, 65, 475-477.

25. Chiang, Y.M.; Chang, J.Y.; Kuo, C.C.; Chang, C.Y.; Kuo, Y.H. Cytotoxic triterpenes from the aerial roots of Ficus microcarpa. Phytochemistry 2005, 66, 495-501.

26. Boiteau, P.; Pasich, B.; Ratsimamanga, A.R. Les triterpenoides en physiologie vegetale et animale (in French); Gautier-Villars: Paris, France, 1964; p. 1370.

27. Pettit, G.R.; Numata, A.; Gragg, G.; Herald, D.L.; Takada, T.; Iwamoto, C.; Riesen, R.; Schmidt, J.M.; Doubek, D.L.; Goswami, A. Isolation and structures of Schleicherastatins 1-7 and Schleicheols 1 and 2 from the teak forest medicinal tree Schleichera oleosa. J. Nat. Prod. 2000, $63,72-78$.

28. Dekebo, A.; Dagne, E.; Gautun, O.R.; Aasen, A.J. Triterpenes from the resin of Boswellia Neglecta. Bull. Chem. Soc. Ethiop. 2002, 16, 87-90.

29. Bondet, V.; Brand-Williams, W.; Berset, C. Kinetics and mechanisms of antioxidant activity using the DPPH free radical method. LWT Food Sci. Technol. 1997, 30, 609-615.

30. Benzie, I.F.F.; Strain, J. The ferric reducing ability of plasma (FRAP) as a measure of antioxidant power: the FRAP assay. Anal. Biochem. 1996, 239, 70-76.

Sample Availability: Samples of the compounds 1a, $\mathbf{2}$ and $\mathbf{3}$ are available from the authors.

(C) 2012 by the authors; licensee MDPI, Basel, Switzerland. This article is an open access article distributed under the terms and conditions of the Creative Commons Attribution license (http://creativecommons.org/licenses/by/3.0/). 